\title{
CORPORATE VENTURE CAPITALISTS AND INDEPENDENT VENTURE CAPITALISTS: WHAT DO THEY KNOW, WHO DO THEY KNOW, AND SHOULD ENTREPRENEURS CARE?
}

\author{
Markku Maula, Helsinki University of Technology \\ Erkko Autio, Helsinki University of Technology \\ Gordon Murray, London Business School
}

\section{CHAPTER MENU}

\author{
ABSTRACT \\ INTRODUCTION \\ LITERATURE REVIEW AND HYPOTHESIS DEVELOPMENT \\ HYPOTHESES \\ DATA AND METHODS \\ RESULTS \\ DISCUSSION \\ CONTACT \\ REFERENCES \\ TABLE 1 \\ TABLE 2
}

\begin{abstract}
While a strong stream of research has examined the value-added by venture capitalists and some recent research has also explored the value added by corporate venture capitalists, the value-added provided by these two types of investors for their portfolio companies has not been compared systematically. This study proposes to make such an evaluation by comparing the social capital based and knowledgebased forms of value added provided by independent and corporate venture capitalists to their portfolio firms. Employing primary data collected from U.S. technology-based new firms that had recently received both corporate venture capital and independent venture capital funding, the present study demonstrates that the value-adding contributions of corporate venture capital and independent venture capital investors are different but complementary.
\end{abstract}

\section{INTRODUCTION}

Past research has examined the value-added provided by independent venture capitalists for their portfolio companies. Recently, some studies have also started to examine the value-adding contributions made by corporate venture capitalists to the commercial success of their portfolio firms. However, so far, there have been no studies that have rigorously compared and evaluated the distinct contributions of each of these two types of investors when they are present as co-investors. This current study proposes to make such an evaluation by comparing the social capital based and knowledge-based forms of value added provided by independent and corporate venture capitalists to their portfolio firms. Employing primary data collected from U.S. technology-based new firms that had recently received both corporate venture capital and independent venture capital funding, the present study demonstrates that the value-adding contributions of corporate venture capital and independent venture capital investors are different but complementary. 
We draw eclectically on the social capital theory and the knowledge-based and learning frameworks to develop hypotheses of the value-adding benefits of corporate and independent venture capital investors for their portfolio firms. The hypotheses are tested using primary data on 91 matched pairs of dyads between U.S. technology-based new firms and their most important CVC and VC investors, respectively. We employ univariate analyses and multiple regression analysis to test the hypotheses.

To our knowledge, this is the first rigorous empirical study that compares the forms and importance of various value-added forms of CVC and VC investors by employing primary data collected from CEOs of technology-based new firms. The research also contributes to the literature on firm-specific and relational social capital by demonstrating how differences between the two types of investors influence the social capital leveraged in the investor-investee dyads.

The findings have also important performance implications for the commercial activities of both the corporate and independent venture capital investors as well as for the entrepreneur. When acting cooperatively within investment syndicates both types of investor have the ability to provide their common portfolio companies with value adding, complementary capabilities that are made more effective by the generation of social capital. The empirical evidence suggests strongly that these two investment vehicles are not substitutes but exhibit strong positive additionalities.

\section{LITERATURE REVIEW AND HYPOTHESIS DEVELOPMENT}

\section{Earlier Research on Investor Value-Added}

In earlier studies examining the nature of value-added support provided by independent venture capitalists, MacMillan et al. (1988) reported that activities attracting the highest degree of venture capitalists involvement were: (1) serving as a sounding board to the entrepreneur team, (2) helping the firm obtain alternative further sources of equity financing, (3) interfacing with the investor group, (4) monitoring financial performance, (5) monitoring operating performance, and (6) helping their portfolio firms attract alternative sources of debt financing. Quite similarly, Gorman and Sahlman (1989) documented a ranked order of the forms of assistance as follows: (1) help with obtaining additional financing, (2) strategic planning, (3) management recruitment, (4) operational planning, (5) introductions to potential customers and suppliers, and (6) resolving compensation issues. Sapienza et al. have conducted several studies on sources of value-added provided by both U.S. and European venture capitalists. In their studies, strategic roles ranked highest followed by interpersonal roles (Sapienza et al., 1994; 1996). Strategic roles included acting as a sounding board as well as being a finance and business advisor. Rosenstein et al. (1993) also examined this issue from the CEO's perspective and concluded that most important roles for professional equity providers were principally monitoring financial performance, serving as a sounding board to the entrepreneur team and recruiting/replacing the CEO. Synthesizing the results of earlier studies, the most valuable contributions of independent venture capitalists, other than the initial provision of capital, are in arranging additional financing, supporting strategy making, and recruiting key executives.

There is significantly less research on the value-added provided by corporate venture capitalists. Previous research by Maula \& Murray (2000) and numerous practitioner accounts suggest that corporate venture capital investment managers may, similarly, have an important role in improving the public legitimacy of young, unknown ventures. Partly because of this certification benefit, corporate venture capitalists are seen to have an important role in helping the young firm attract new commercial partners and customers. Additionally, corporate venture capitalists can offer tangible technical support given that industry-leading corporations are highly active and influential in the development of related technologies and in defining the direction of future innovation via their involvement in the creation of industry-wide, technology roadmaps. Recently, Maula (2001) developed a model of three main mechanisms through which portfolio companies receive value-added from their corporate venture capital investors: resource acquisition, knowledge acquisition, and endorsement. Resource acquisition refers to concrete resources such as distribution channels or production capacity. Knowledge acquisition refers to learning for instance from technology, markets, competition. Endorsement refers to the increased credibility caused by the affiliation with a large corporation. The model was validated using primary data from U.S technology-based new firms. 
In this study, we focus on two kinds of value-added forms. First, we consider benefits based on the social capital of the investors. We assume that there are differences in the social networks of independent and corporate venture capital investors, differences in who they know. These differences should be reflected in their value added. Secondly, we expect to see differences in the competence areas of the two types of investors, differences in what they know. Also, these differences should be reflected in their value added. Overall, we construct nine hypotheses for testing. Using direct feedback from the portfolio firms, we seek to identify, differences between independent venture capitalists or a corporate venture capitalists in terms of their ability to add value to their portfolio firms. Finally, we examine whether the different types of value-added are differently related to the overall value-added perceived by the entrepreneurs.

\section{HYPOTHESES}

\section{Value Added Based on Social Capital}

Social capital to attract financing. One of the common roles of equity investors is helping the growing company obtain new financing when needed (Gorman \& Sahlman, 1989; MacMillan et al., 1998; Sapienza et al., 1996). Because of the staged nature of venture capital financing, companies typically seek several rounds of investments before they are commercially mature enough for a liquidity event. Independent venture capitalists are financial professionals. Their single key objective is to maximize the financial returns of their fund and thus the economic rewards of their investors (limited partners). In so doing, they maximize their own financial rewards via the carried interest incentive structure. Venture capitalists typically cultivate a broad network of commercial partners and allies in the financial markets. This network will include investment bankers and other venture capitalists. In comparison, corporate venture capitalists often prioritize strategic goals above financial goals. As a consequence, corporate venture capitalists may possess smaller and less valuable social networks within the financial community. Also, the generally smaller experience of corporate venture capitalists at deal making causes them to prefer to invest via syndication. Given their relatively greater experience, the venture capital firm commonly acts as the lead investor and takes primary responsibility for assessing the valuation and determining the financial structure of the deal. Therefore, we hypothesize that independent venture capitalists will have a more dominant role in helping to arrange additional financing for portfolio firms.

Hypothesis 1: VCs are more valuable in helping portfolio companies obtain additional financing than CVCs.

Social capital to attract key executives. Another often cited role of venture capitalists is to help in the identification and hiring of key executives in order to realize the growth plans of their portfolio companies (Gorman \& Sahlman, 1989; Rosenstein et al., 1993). Whereas independent venture capitalists work with a wide network of people outside of their own organizations, the experience and contacts of corporate venture capitalists may be more defined by and focused on their own corporation. We hypothesize that independent venture capitalists are likely to be viewed by portfolio firms as more valuable in helping to recruit key management.

Hypothesis 2: VCs are more valuable in helping portfolio companies recruit new employees than CVCs.

Social capital to attract partners. Venture capitalists may be admired for their commercial acumen and financial knowledge. However, they are likely to have relatively less authority in areas that directly relate to the core business of the portfolio firm. Because of their corporate background, it may well be that only the name of an internationally respected corporate partner is sufficient to attract business partners (Kelley \& Spinelli, 2001). In biotechnology, for example, it is often difficult for an outsider investor to assess with sufficient accuracy the potential of a new technology. In such cases, the investment by a respected "big pharma" corporation may effectively signal the attractive prospects of the start-up to less informed outsiders. As such, the actions of the corporate investor help reduce information asymmetries that may limit the future prospects of the start-up company. Robert Young, the CEO of Red Hat Linux, commented after receiving corporate venture capital investments from Intel and Netscape: "The significance of closing this round with Intel and Netscape was that it made Linuxbased operating systems safe for the major application vendors, including Oracle, Corel, and Computer 
Associates. They would now be willing to sell their applications to their customers running on Red Hat Linux." (Young \& Rohm, 1999). Thus, we hypothesize that corporate venture capitalists are better at helping their portfolio companies to attract partners.

Hypothesis 3: CVCs are more valuable in helping portfolio companies obtain attract new partners than VCs.

Social capital to attract new domestic customers. A major problem facing virtually all start-ups is that no one, including would-be customers, really knows anything about them. Accordingly, no-one wants to be the first to use their products. As Geoffrey Moore (1995) observed, buyers from large corporations are profoundly risk-averse. They will always insist that some one else is "the guinea pig." Thus, small firms commonly suffer "a liability of alienness" - no one wants to know them until they have a credible track record of business deals (Burgel et al., 2001). This is a Catch 22 situation. They cannot sell to large firms or other important customers-regardless of the quality of their technology and products - until they can demonstrate a track record. But they cannot gain a track record until they sell to large firms or other important customers. Corporate venture capitalists are among the few organizations that have the market power to resolve this impasse easily. Their portfolio companies can be given access to the corporation's worldwide sales and marketing channels. The corporate investor can also become a publicly visible supplier, purchaser, or advocate of the company's products. The young firm may initially be unknown but the fact that GE Capital, Intel Capital, Nokia Venture Partners or Johnson \& Johnson Development Corporation is an investor conveys a huge endorsement benefit to the young and erstwhile "invisible" company. Therefore, we hypothesize that corporate venture capitalists are better at helping their portfolio forms gain wider market credibility and attract customers.

Hypothesis 4: CVCs are more valuable in helping portfolio companies attract new domestic customers than VCs.

Social capital to attract new foreign customers. Whereas venture capital investors typically operate locally (Sorenson \& Stuart, 2001), parent corporations of corporate venture capital investors are typically global corporations. The support from corporate venture capitalists in helping portfolio firms attract new customers is likely to be even more effective when focusing on foreign customers. Many corporate venture capital operations are specialist units of established organizations with global presence and reputations. In contrast, the majority of venture capitalist firms are much more local in both operation and influence. Therefore, we expect that the involvement of corporate venture capital investors is relatively more effective in helping portfolio firms internationalize and attract foreign customers.

Hypothesis 5: CVCs are more valuable in helping portfolio companies obtain new foreign customers than VCs.

\section{Value Added Based on Knowledge}

Knowledge on markets. As established industry players enjoy deep specialist knowledge across a range of related sectors, corporations often have a better understanding of technological developments in their key product markets. Technology-based new firms can sometimes lack a broader perspective on the market and customer needs. On the other hand, corporations spend large amounts of money on their market research and operate globally. From their existing customer relationships, they have a different and deeper understanding of the market needs than a start-up developing a product for future markets. Access to the market understanding of the large corporation may be invaluable for a technology-based new firm (Dube, 2000:49; Maula \& Murray; 2000).

Hypothesis 6: CVCs are more valuable in providing information on customer needs and trends than VCs.

Knowledge on competition. Large corporations primarily compete against other large corporations. They are very likely to ignore or not even notice small start-ups. Traditionally trained corporate managers may have little direct understanding or interest in the world as seen by a new firm. In 
contrast, the role of venture capital managers centers on the nurturing and growth of firms which while economically small today might become the industry leaders of tomorrow. When considering the actual development of the young firm's business strategy, it has been found that one of the most important forms of value-added provided by independent venture capitalists is acting as a sounding board to management in order to help develop the firm's strategic plans and goals. Therefore, we hypothesize that independent venture capitalists are more likely to provide start-ups with information on competition.

Hypothesis 7: VCs are more valuable in providing information on competition than CVCs.

Knowledge on technology. The over-riding goal of the majority of corporate venture capitalists is to add strategic value for their corporate parent organization (Keil, 2000; McNally, 1997; Siegel et al., 1988; Sykes, 1990). Given that most corporations active in corporate venture capital are from technology intensive industries, knowledge on technology is likely to be one of the core benefits they can also provide for their portfolio companies. Both parties can gain reciprocally from detailed technical knowledge and insights held by either the corporation or the highly focused young firm. As investors, corporations generally have an ability to undertake technical "due diligence" in their areas of technical competence with a level of rigor and depth of resources unavailable and inaccessible to even the largest private venture capital firm. Consider the words of John M. Troyer, a co-founder of Neomar, a developer of wireless internet products who chose two corporations active operating in the wireless market as their external investors: "We felt like many of the venture firms we talked to didn't have a clear understanding of the wireless space yet" (The Corporate Venturing Report, 2001). Therefore, we hypothesize that corporate venture capitalists are likely to be seen as stronger in the technology related knowledge they provide for their portfolio companies.

Hypothesis 8: CVCs are more valuable in providing information on new technologies than VCs.

Knowledge on organizing. Independent venture capitalists are often experienced entrepreneurs themselves. As venture capitalists, they have followed, monitored, and guided numerous start-ups from firm formation and the initial investment to the eventual liquidity event at which these professional investors will exit the business. In contrast, many of the career managers recruited internally into the corporate venture capital divisions have their backgrounds exclusively in the corporate world. Accordingly, they view start-ups and their commercial environments largely from a more limited corporate perspective. Therefore, we hypothesize that independent venture capitalists have greater and wider experiences with which to help portfolio companies manage early growth.

Hypothesis 9: VCs are more valuable in helping organize for growth than corporate VCs.

\section{DATA AND METHODS}

\section{Data}

The hypotheses were tested using data from a survey administered to CEOs and founders of CVC financed U.S. technology-based new firms in December 2000. CVC backed companies were identified from the Venture Economics database. A technology-based new firm was defined as a firm less than 6 years old and operating in one of the following sectors: biotechnology, medical/health science, internet specific, communications, computer software and services, computer hardware, or semiconductors/other electronics. We also required that the venture had received funding from at least one independent venture capitalist. Companies that had been acquired, had gone public, or had subsequently ceased operation were excluded. We also required that the most recent investment in the portfolio company had been made within the last two years in order to ensure that the relationship was still active. Finally, we excluded ventures that were found to be originally spin-offs from the corporation currently acting as a corporate investor in order to preserve the perspective of a new venture having accepted corporate venture capital financing.

The sampling frame consisted of the entire population of 810 privately-held technology-based new firms fulfilling the selection criteria at the time of the survey (November 2000-January-2001). Of the 135 questionnaires received, 91 met all sample selection criteria and were sufficiently complete. This 
translates to a response rate of $17 \%$, which can be considered acceptable given that it was requested that the four-page questionnaires be completed by CEOs. In this population, the average age of the firms was just over three years, with an average of \$55 million external investment. With average revenues of less than $\$ 5$ million per year, the CEOs of these companies were likely to be under strong investor pressure to grow their business rapidly.

Non-response bias was analyzed by comparing the age, geographic location, and industry sectors between the respondent and the non-respondent firms. We conducted further response bias analysis by comparing statistically the number of employees and the revenues of early and late respondents. For all tests, no significant biases were detected.

Several methods were used to ensure the validity and reliability of the data. First, we pre-tested the four-page survey instrument with several CEOs and CVC investors. In the instrument, previously validated constructs and measurement items were used whenever possible. Multi-item constructs were used for most primary variables in order to enhance content coverage. In all but one case, our multiitem constructs achieved construct reliabilities of .74 or higher, thus indicating good internal consistency.

\section{Measures}

Ten constructs are used to test the hypotheses. In pairwise univariate comparisons we compare the activity of the two types of investors in nine areas of value-added. In the regression analyses, we test the roles of these nine types of value-added in explaining the overall value-added and satisfaction in the two types of relationships.

The overall value-added was measured using a multi-item scale measuring the overall satisfaction of the key informants. The construct was operationalized using three measurement items: "This investor has provided us valuable value adding support in addition to the financing," "The value adding support provided by this investor has been critical for our success," and "We are very happy about having this investor." The Cronbach's alpha inter-item reliability coefficient for this construct is .87. To ensure the reliability of the construct a follow-up survey measuring the CVC relationships was administered for the original respondents six months after the original survey. The original value-added construct and the 6 months lagged construct were highly correlated $(r=.576, p<=.001)$ suggesting good reliability for this construct. Furthermore, a one-way ANOVA, using firm identity as the independent variable, revealed that between firm-variance was significantly greater than within-firm variance $(p<=.001)$, indicating significant agreement between the original and the lagged ratings. Together, these tests provided additional evidence of construct validity.

The forms of value-added were divided in two groups: social capital based forms of value-added and knowledge-based forms of value-added. In the first group, the value-added forms were related to the support in attracting five types of resources: 1) additional investors; 2) key employees; 3) partners; 4) domestic customers; and foreign customers. All of these constructs were defined using four indicators. Cronbach's alpha inter-item reliability coefficients for these constructs varied between .74 and .93.

In the second group, the value-added forms were related to the advice based on four types of knowledge: 1) markets; 2) competition; 3) technology; 4) organization. All of these constructs were defined using two indicators. For market knowledge of VCs, the reliability was only .63. For all the others, the reliabilities ranged between .77 and .92 .

\section{RESULTS}

We first tested the hypotheses using pairwise comparisons of the value-added forms between most important VC and CVC investors of the sample companies. The results are presented in Table 1. In general, the results support our hypotheses. Independent venture capitalists were found to be viewed as better at helping portfolio companies obtain new financing, recruiting key employees, and helping develop the organization. In contrast, corporate venture capitalists appear to be stronger helping startups attract new partners, helping them attract new domestic and foreign customers, and helping start-ups develop their technology. 
Using multiple regression analysis, we tested whether the value-added forms contribute differently to the overall value-added in the two types of relationships. The regression results are presented in Table 2. While the Chow test was not statistically significant, there are significant differences in the importance of individual forms of value-added.

Whereas pairwise comparison indicated that VCs have a more visible role in attracting further financing, the regression analysis showed that this activity is a significant determinant also in the CVC relationships. However, while recruiting key employees was a significant determinant of value-added in VC relationships, it was insignificant in CVC relationships. Attracting partners was not a significant determinant in either type of relationships. The results were the same for domestic customers.

Attracting foreign customers was not significant determinant of value-added in VC relationships but was significant in CVC relationships.

Concerning the differences in the importance of knowledge-based value-added, market knowledge was not a significant determinant in either types of relationships. However, in VC relationships, competitor knowledge was weakly significant. Technological knowledge was not significant in VC relationships, but was significant in CVC relationships. Finally, organizing knowledge was very significant in VC relationships but not significant in CVC relationships.

\section{DISCUSSION}

In this paper, we set out to examine how differences in the social capital and competencies of independent venture capitalists and corporate venture capitalists are reflected in the value-added they provide for their portfolio companies. We first tested the differences in the support in various areas and thereafter examined the importance of these areas for the perceived overall value-added. We found that VC investors seem to make entrepreneurs happy by arranging financing, recruiting key employees, advising on competition, and developing organization. CVC investors seem to make entrepreneurs happy also by attracting further financing, but also by attracting foreign customers, and advising on technology.

The value-added forms provided by independent venture capitalists can be classified as "enterprise nurturing." The collective experience of the venture capitalists, many of whom have advised literally dozens of entrepreneurs on the challenges of enterprise formation and early-stage growth, represents a potentially enormously valuable resource. Venture capitalists particularly can advise with authority thereby enabling the young firm to avoid many of the mistakes to which new businesses are particularly vulnerable. The value-added forms actively contributed by corporate venture capitalists relate directly to the trading and commercial environment of the new business and can be termed "commerce building." Here the emphasis is not on the structure and organization of the new enterprise but on its ability to forge revenue generating opportunities form its contractual relationships with both customers and suppliers. In these production/product/market areas, the corporation has greater experience and authority.

The key conclusion from the research is that corporate venture capitalists and independent venture capitalists have different and complementary value-added profiles. Independent venture capitalists appear to have superior enterprise nurturing skills. They can better help entrepreneurial founders transform their ideas into viable companies through their skills and experience in developing strategy, obtaining additional financing and helping to recruit key employees. On the other hand, corporate venture capitalists appear to have a stronger role in in-creasing the commercial and public credibility of their portfolio forms through their deep, commerce building experience. Their public involvement as investors, given their international status, helps young firms attract customers, suppliers, and partners. Finally, the young firm's involvement with sophisticated technology and research based corporations also has a direct benefit in helping support the technological developments of the young firm.

\section{Implications for Technology-Based New Firms and Investors}

A clear practical implication of this study is that careful investor selection is extremely important for start-up CEOs. As documented by Smith (2001), start-ups often do have some choice in this matter. Depending of the specific array of needs of the start-up company, an optimal "value-added portfolio" 
may be constructed by specifically selecting both independent venture capital investors and corporate venture capitalists based on these investors' ability to each provide complementary support and advice in their respective areas of strength. Similarly, given that both types of investors are also seeking to build successful companies albeit for different objectives, co-operative syndication may equally further their own interests more efficiently than if they invested in isolation.

\section{Implications for Research}

This paper has demonstrated that independent venture capital investors and corporate venture capital investors have different social capital and knowledge to offer to their portfolio companies. This has been the first paper to empirically examine the differences in the value added and to examine the main types of social capital and knowledge offered by both types of investors that influence the overall value-added and satisfaction of the entrepreneurs. In future research, it would be interesting to examine whether there are differences in the factors that influence the perceived usefulness of the value-added of the two types of investors.

CONTACT: Markku Maula, Helsinki University of Technology, Institute of Strategy and International Business, P. O. Box 9500, FIN-02015 HUT, Finland; (T) +358 40556 0677; (F) +358 9451 3095; markku.maula@hut.fi

\section{REFERENCES}

Burgel, O., A. Fier, G. Licht, \& G.C. Murray. (2001) The Rapid Internationalisation of High Tech Young Firms in Germany and The United Kingdom. London \& Berlin: The Anglo German Foundation.

Dube, M.R. (2000) 'Intel Stands Tall Among Corporate Investors." In The Corporate Venturing Directory and Yearbook, ed. D. Barry, 47-50. Wellesley, MA: Asset Alternatives, Inc.

Gorman, M., \& W.A. Sahlman. (1989) “What Do Venture Capitalists Do?” Journal of Business Venturing 4: 231-248.

Kann, A. (2000) "Strategic Venture Capital Investing by Corporations: A Framework for Structuring and Valuing Corporate Venture Capital Programs." Unpublished dissertation, Stanford University.

Keil, T. (2000) External Corporate Venturing: Cognition, Speed, and Capability Development. Doctoral Dissertation, Institute of Strategy and International Business, Helsinki University of Technology.

Kelley, D., \& S. Spinelli. (2001) "The Role of Corporate Investor Relationships in the Formation of Alliances for Corporate Venture Capital Funded Startups.” Paper presented at the Babson CollegeKauffman Foundation Entrepreneurship Research Conference 2001.

MacMillan, I.C., D.M. Kulow, \& R. Khoylian. (1988) "Venture Capitalists' Involvement in Their Investments: Extent and Performance." Journal of Business Venturing 4: 27-47.

Maula, M.V.J, \& G.C. Murray. (2000) "Corporate Venture Capital and the Creation of US Public Companies: The Impact of Sources of Venture Capital on the Performance of Portfolio Companies." Forthcoming in: Creating Value: Winners in the New Business Environment, ed. M.A. Hitt, R. Amit, C. Lucier, \& R.D. Nixon. Oxford: Blackwell Publishers.

Maula, M.V.J. (2001) Corporate Venture Capital and the Value-Added For Technology Based New Firms. Doctoral dissertation, Helsinki University of Technology.

McNally, K. (1997) Corporate Venture Capital: Bridging the Equity Gap in the Small Business Sector. London: Routledge. 
Moore, G.A. (1995) Inside the Tornado: Marketing Strategies from Silicon Valley's Cutting Edge. New York: Harper Business.

Rosenstein, J., A.V. Bruno, W.D. Bygrave, \& N.T. Taylor. (1993) “The CEO, Venture Capitalists, and the Board." Journal of Business Venturing 8: 99-113.

Sapienza, H.J., A.C. Amason, \& S. Manigart. (1994) "The Level and Nature of Venture Capitalist Involvement in Their Portfolio Companies: A Study of Three European Countries." Managerial Finance 20(1): 3-17.

Sapienza, H.J., S. Manigart, \& W. Vermeir. (1996) "Venture Capitalist Governance and Value-added in Four Countries.” Journal of Business Venturing 11: 439-469.

Siegel, R., E. Siegel, \& I.C. MacMillan. (1988) "Corporate Venture Capitalists: Autonomy, Obstacles, and Performance.” Journal of Business Venturing 3: 233-248.

Smith, G. (2001) "How Early Stage Entrepreneurs Evaluate Venture Capitalists?" Journal of Private Equity (4)2: 33-46.

Sorenson, O., \& T.E. Stuart. (2001) "Syndication Networks and the Spatial Distribution of Venture Capital Investment.” American Journal of Sociology 106: 1546-1588.

Sykes, H.B. (1990) "Corporate Venture Capital: Strategies for Success." Journal of Business Venturing 5: 37-47.

The Corporate Venturing Report, January 2001, Page 20.

Young, R. \& W.G. Rohm. (1999) Under the radar: how Red Hat changed the software business-and took Microsoft by surprise. Scottsdale, AZ: The Coriolis Group.

Table 1

Differences in Provision of Various Value-Added Forms Between VCs and CVCs

\begin{tabular}{|c|c|c|c|c|}
\hline Form of value-added & $\begin{array}{c}\text { Independent } \\
\text { venture capitalists }\end{array}$ & $\begin{array}{c}\text { Corporate } \\
\text { venture capitalists }\end{array}$ & $\begin{array}{c}\text { Painwise t-test } \\
\text { of difference }\end{array}$ & $\begin{array}{c}\text { Sigrificance } \\
\text { level } \\
\text { (1-tailed test) }\end{array}$ \\
\hline SC Finance & 6.03 & 4.54 & 9.152 & $.000 * * *$ \\
\hline SC Employees & 501 & 3.91 & 6.714 & $.000^{* * * *}$ \\
\hline SC Partners & 4.44 & 4.32 & 0.671 & .504 \\
\hline SC Domestic customers & 3.91 & 4.24 & -1.726 & $.088+$ \\
\hline SC Foreign customers & 2.90 & 3.58 & -3.421 & .001 ***** \\
\hline K Markets & 3.93 & 4.48 & -2.982 & $.004^{* * *}$ \\
\hline $\mathrm{K}$ Competitors & 3.99 & 3.81 & 1.037 & .303 \\
\hline $\mathrm{K}$ Technology & 3.02 & 3.76 & -3.452 & .001 **** \\
\hline K Orgarization & 4.54 & 2.76 & 8.231 & .000 **** \\
\hline
\end{tabular}

Significantly higher value added contributions bolded 


\section{Table 2}

Regression Results on Overall Value-Added by VCs and CVCs

\begin{tabular}{|c|c|c|}
\hline Form of value-added & $\begin{array}{c}\text { Independent } \\
\text { venture capitalists }\end{array}$ & $\begin{array}{c}\text { Corpor ate } \\
\text { venture capitalists }\end{array}$ \\
\hline SC Finance & $.150 *$ & $.196 *$ \\
\hline SC Employees & $.451 * * *$ & .127 \\
\hline SC Partners & .006 & .083 \\
\hline SC Domestic customers & -.091 & .064 \\
\hline SC For eign customers & .069 & $.151+$ \\
\hline KMrkets & .069 & .120 \\
\hline $\mathrm{KC}$ ompetitors & $.164+$ & .110 \\
\hline K Technology & .100 & $.238 *$ \\
\hline KOrganization & $.228 * *$ & -.094 \\
\hline Adjusted $R^{2}$ & .587 & .557 \\
\hline
\end{tabular}

Source: http://www.babson.edu/entrep/fer/Babson2002/XIII/XIII_P6/XIII_P6.htm (at 21/11/2007, 14:30) 
